\title{
SHORT-TIME MEASUREMENTS OF INTERCEPTION IN MOUNTAIN SPRUCE FOREST
}

\author{
LADISLAV HOLKO
}

Institute of Hydrology, Slovak Academy of Sciences, Ondrašovská 16, 03105 Liptovský Mikuláš, Slovakia; Mailto: holko@uh.savba.sk, tel., fax +421445522522

Open area rainfall and throughfall measurements in the Western Tatra Mountains (altitude about $1500 \mathrm{~m}$ a.s.l.) made by tipping bucket gauges were used to estimate the usefulness of the short-time data in analysis of spruce interception. The 10-minute data from period 13 May-13 October 2009 did not reveal meaningful correlations between the open area rainfall and throughfall. Aggregated measurements representing individual rainfall events were more useful. They showed linear relationship between open area rainfall and throughfall for events with total rainfall depth in the open area exceeding $5 \mathrm{~mm}$. Correlation between open area rainfall and throughfall for rainfall events with duration above 120 minutes was significantly better than for the shorter ones. Mean values of interception (percentage of open area rainfall which did not appear in throughfall) of individual rainfall events was high. When we excluded events for which throughfall was higher than the open area rainfall, mean interception for larger and longer rainfall events was $46 \%$ and $48 \%$, respectively. For smaller (runoff depth below $5 \mathrm{~mm}$ ) and shorter events (duration below 2 hours) the mean interception was $70 \%$ and $72 \%$, respectively. However, the data revealed very high variability of interception.

KEY WORDS: Interception, Short-time Data, Mountain Spruce Forest.

Ladislav Holko: MERANIE INTERCEPCIE V HORSKOM SMREKOVOM LESE V KRÁTKOM ČASOVOM KROKU. J. Hydrol. Hydromech., 58, 2010, 4; 32 lit., 5 obr., 1 tab.

Príspevok sa zaoberá hodnotením užitočnosti krátkodobých meraní zrážok na otvorenej ploche a v smrekovom lese pri určovaní intercepcie. Vychádza z merania zrážok preklápacími zrážkomermi v Západných Tatrách v nadmorskej výške okolo $1500 \mathrm{~m}$ n.m. Desat'minútové údaje merané v období 13.5.13.10.2009 neposkytli použitel’né korelácie medzi dažd’om na otvorenej ploche a v lese. Lepšie výsledky boli získané pre sumárne úhrny zrážok pre jednotlivé dažde. Ak úhrn dažd’a na vol’nej ploche prekročil približne $5 \mathrm{~mm}$, vel'kost' podkorunových zrážok rástla lineárne s vel'kost'ou zrážok na vol'nej ploche. Korelácia medzi zrážkami na vol’nej ploche a v lese pre dažde $\mathrm{s}$ dlžkou trvania nad 120 minút bola podstatne lepšia, ako pre kratšie dažde. Priemerná hodnota intercepcie (vyjadrenej ako percento zrážok na vol'nej ploche, ktoré sa neobjavilo v lese) pre jednotlivé zrážkové udalosti bola vysoká. Po vylúčení udalostí, pre ktoré bol v lese nameraný vyšší úhrn zrážok ako na vol’nej ploche, bola priemerná intercepcia pre väčšie dažd’e $46 \%$ a pre dlhšie dažde $48 \%$. Pre menšie (úhrn pod $5 \mathrm{~mm}$ ) a kratšie (trvanie pod 2 hodiny) dažde bola priemerná intercepcia $70 \%$ a $72 \%$. Hodnoty intercepcie pre jednotlivé udalosti však mali vel'kú variabilitu.

KLÚČOVÉ SLOVÁ: intercepcia, krátkodobé údaje, horský smrekový les.

\section{Introduction}

Vegetation influences hydrological cycle in many ways. One of them is the influence on partitioning of water inputs into the catchment (soils) by precipitation interception. Hundreds studies were devoted to interception worldwide. In Europe, the comparative studies of precipitation in forested and open areas were performed already in the $19^{\text {th }}$ cen- tury in Germany, Austria, Switzerland, France and Russia (e.g. Krečmer, 1952). The review given by Helvey and Patric (1965) shows that interception has been of much interest in the United States since the first third of the $20^{\text {th }}$ century and the description of canopy interception was made already in 1893 . Throughfall and stemflow values for different tree species depending on the amount of rainfall were given by Hoppe already in 1896 (in Krečmer, 
1952). Similar studies were repeated many times. Yet, Savenije (2004) noted that many hydrological models still disregard or underestimate interception, although it is one of the most important processes in hydrological modeling.

Studies based on comparison of open area rainfall and throughfall usually give the longer-time, e.g. seasonal or annual values of interception. Such values are useful, e.g. in the analysis of water balance. In other applications, e.g. in hydrological modeling, understanding of runoff formation in the catchment, soil moisture distribution or erosion, the knowledge of interception in the short time intervals (during individual rainfalls) may be more important (e.g. Horvát et al., 2009). Since the longerterm values known from field measurements can not be directly used in such applications, interception modeling is necessary. Several approaches were developed to model the rainfall interception. A brief description of the models including the empirical ones was earlier provided e. g. by Xiao et al., 2000. A more detailed review of physically based interception modeling was recently made by Muzylo et al. (2009). They reported on 15 physically based interception models, the youngest of which was proposed in 2007.

Generally, the physically based interception models can be divided into several groups (e.g. Muzylo et al., 2009). The Rutter type models (e.g. Rutter et al., 1971; Benetin, 1983; Massman, 1983; Liu, 1988; Xiao et al., 2000) represent interception by water balance of rainfall input, storage and output (drainage, evaporation):

$\frac{d C}{d t}=\left(1-f_{g}-f_{s}\right) p-D_{0} \exp (b(C-S))-e$,

where $C$ is canopy water storage [mm], $f_{g}-$ a gap fraction that controls the precipitation contributing to free throughfall, $f_{s}-$ the precipitation fraction contributing to stemflow, $D_{0}$ and $b$-empirical drainage parameters, $S$ - the canopy storage capacity $[\mathrm{mm}], p-$ precipitation rates $[\mathrm{mm}], e$ - evaporation rates [mm], respectively (Xiao et al., 2000).

Gash's type models (Gash, 1979; Mulder, 1985; Zeng et al., 2000, Murakami, 2007) are analytical models that provide a simplified solution to the Rutter's model (Muzylo et al., 2009). Rainfall input is represented as a series of discrete storms between which the canopy and stems completely dry. Gash's model can be written (Xiao et al., 2000):

$$
\begin{aligned}
& \sum_{j=1}^{N+M} I L_{j}=N\left(1-f_{g}-f_{S}\right) P^{\prime}+\frac{\bar{E}}{\bar{R}} \sum_{j=1}^{N}\left(P_{j}-P^{\prime}\right)+ \\
& +\left(1-f_{g}-f_{S}\right) \sum_{j=1}^{M} P_{J}+E_{\text {trunk }} \\
& E_{\text {trunk }}=J S_{t}+f_{S} \sum_{j=1}^{M+B-J} P_{j}, \\
& P^{\prime}=-\frac{\bar{R} S}{\bar{E}} \ln \left(1-\frac{\bar{E}}{\bar{R}\left(1-f_{g}-f_{S}\right)},\right.
\end{aligned}
$$

where $I L$ is total interception loss [mm], $\bar{E}$ and $\bar{P}$ - mean evaporation and rainfall rates $[\mathrm{mm}], S_{t}-$ trunk storage capacity [mm] and $J$ - the number of events above the critical rainfall $\left(S_{t} / f_{s}\right) . M$ is the number of events that are insufficient to saturate the canopy surface completely, $N$ - the number of events that are large enough to completely saturate the canopy surface.

Calder (1986) developed a conceptually different model which employs Poisson probability distribution to estimate the number of raindrops that strike the canopy and are retained by it (Muzylo et al., 2009).

The above equations give an idea on parameters of different models. Basically, the parameters characterize water storage, canopy structure, water partitioning and other, e.g. number of drops, raindrop volume, threshold of rainfall intensity, etc. (Muzylo et al., 2009). Vrugt et al. (2003) noted that parameters of the interception models have often to be only calibrated, because it is difficult to validate them by measurements. They also stated that relatively limited research has been conducted to validate the interception models or estimate its parameters from measurements. Inadequate validation of the models, few comparative studies and the uncertainties of measurements and parameters variability were also mentioned by Muzylo et al. (2009).

There are some parameters of interception models which could be inferred from the field measurements. For example, all physically-based interception models reviewed by Muzylo et al. (2009) include some parameter representing the threshold amount of rain that can be stored in the canopy. The main objective of this study was to compare the short-term open area rainfall and throughfall measurements in a mountain spruce forest to obtain information on the interception of individual rainfall events and assess the usefulness of the shorttime measurements in estimation of the canopy 
storage capacity. The study strives to supplement the results of numerous studies conducted in the Western Carpathians by foresters and hydrologists (e.g. Zelený and Tichý, 1968; Majerčáková, 1983; Benetin et al., 1986; Valtýni, 1986; Tužinský, 1995; Lančarič et al., 2001; Mind'áš, 2001; Pekárová et al., 2005, Halmová et al., 2006; Miklánek et al., 2006; Holko et al., 2009) by focusing on the shorttime resolution (10-minutes) rainfall and throughfall data in a high-mountain forest.

\section{Description of study area and measured data}

The study was performed at a small research plot in the Jalovecký creek catchment, the Western Tatra Mountains, northern Slovakia. Open area precipitation was measured in the 10-minutes interval by the tipping bucket raingaiuge at the altitude $1500 \mathrm{~m}$ a.s.1. Throughfall was measured by the tipping bucket gauge in the nearby mature forest spruce (mean age 110 years). Our previous measurements on the site using a number of manually operated rain gauges (Holko et al., 2009) revealed high variability of interception even at the same typical locations (forest window, dripping zone, near stem zone). Therefore, the tipping bucket rain gauge used in this study was placed into a forest window which showed the smallest spatial variability of throughfall in the previous study. Open area and throughfall measurements from period 13 May-13 October 2009 were compared in two steps. First, the short-time interval (10-minutes) data were compared. Second, the data for individual rainfall events were aggregated and compared.

\section{Results}

Most rainfalls in the studied period had intensities of up to about $3 \mathrm{~mm}$ per $10 \mathrm{~min}$ (Fig. 1). Fig. 1 (left panels) shows that the 10-minutes rainfall in the forest was generally smaller than in the open area, started and terminated with small delays after the open area rainfall. Small open area rainfalls were often not registered in the forest. Such a behavior was expected. However, the 10-minutes data did not provide meaningfull correlations of the open area and throughfall rainfalls (Fig. 1 right panel). No correlation between open area rainfall and throughfall exists for rainfall intensities below about $2 \mathrm{~mm} / 10 \mathrm{~min}$. Rainfall compartments of higher intensities tend to have the expected tendency toward more precipitation in the open area, but the scatter is very large.

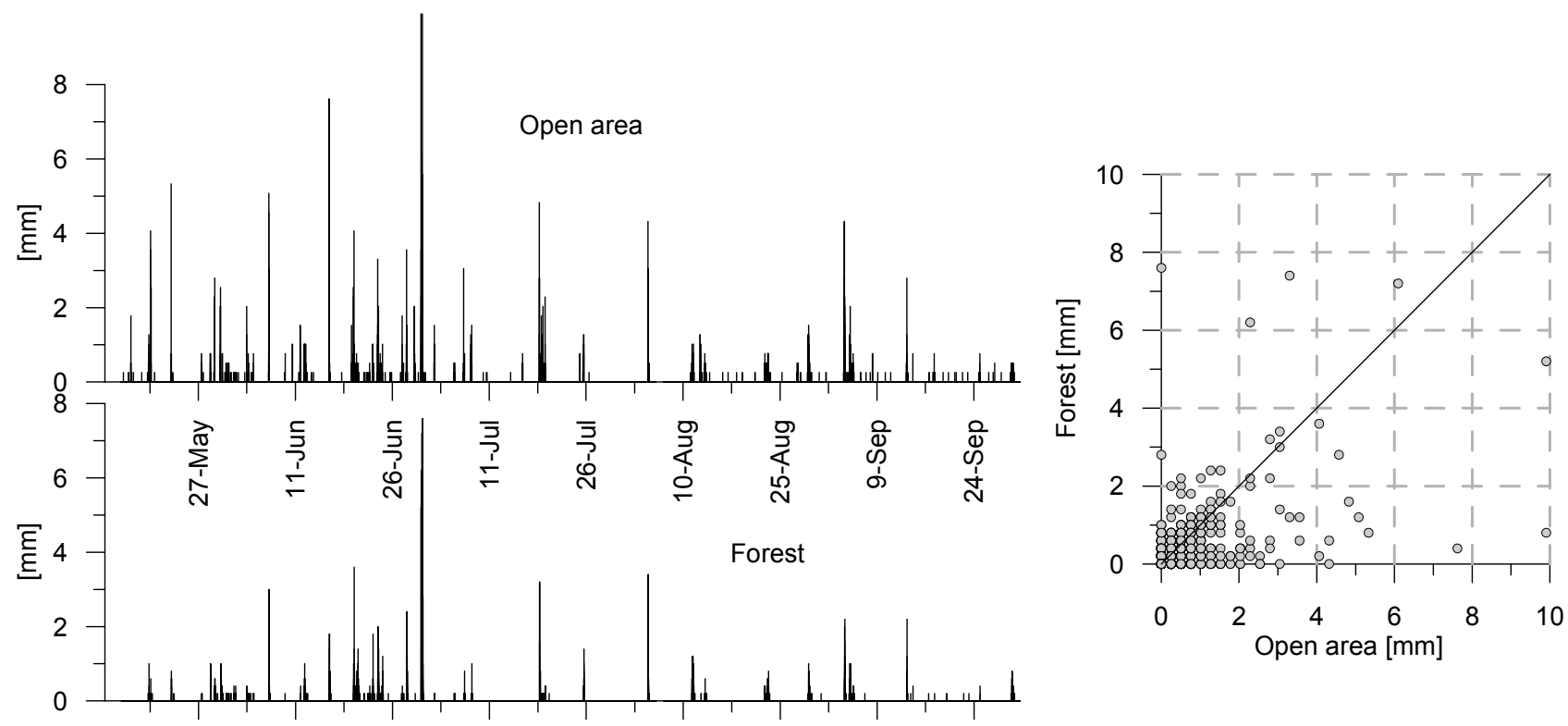

Fig. 1. 10-minute precipitation in the open area and in the forest between 13 May and 13 October 2009; the diagonal in the right panel represents the $1: 1$ line.

Obr. 1. 10-minútové úhrny zrážok na vol'nej ploche a v lese v období 13. 5.-13. 10. 2009; uhlopriečka v pravom obrázku predstavuje čiaru $1: 1$. 

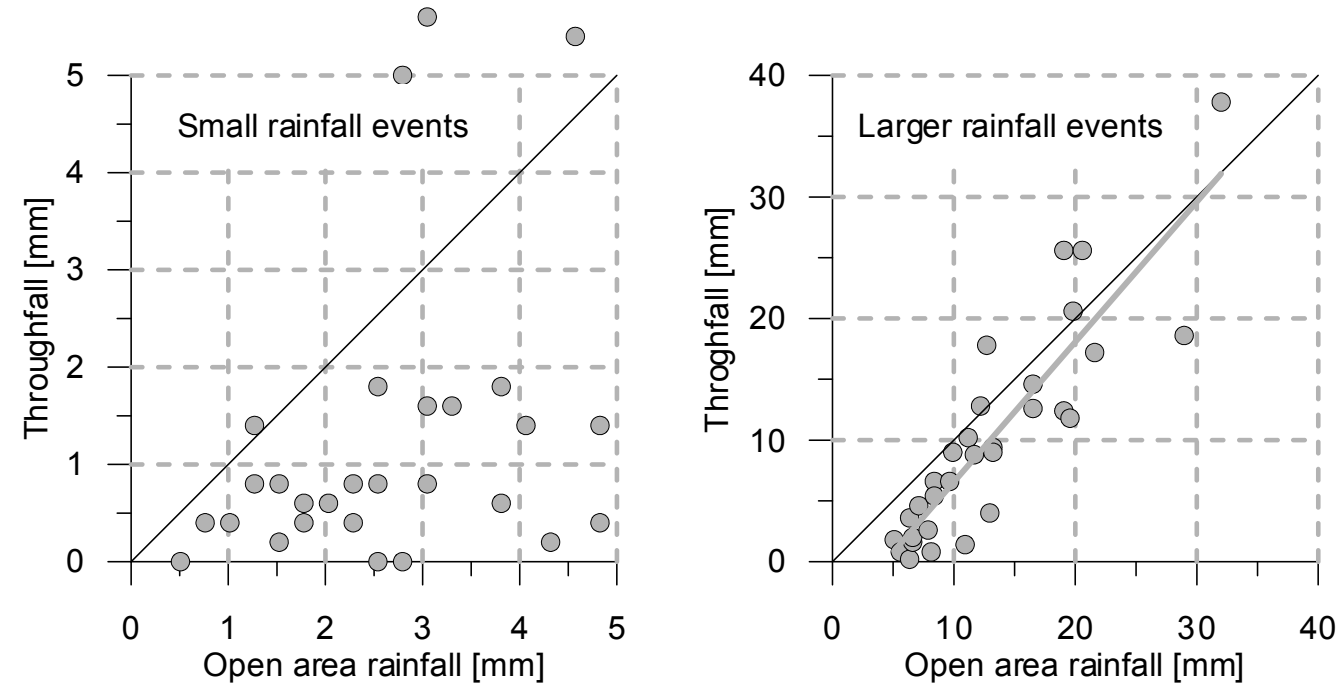

Fig. 2. Rainfall amount and interception; relationship between open area rainfall and throughfall for 59 rainfall events measured between 13 May and 13 October 2009; left - rainfall in the open area reached 0-5 mm; right - rainfall in the open area exceeded 5 $\mathrm{mm}$; the diagonals represent the 1:1 lines; the grey line in the right panel represents the regression line $\left(\mathrm{R}^{2}=0.778\right)$.

Obr. 2. Úhrn dažd’a a intercepcia; vzt'ah medzi zrážkami na vol’nej ploche a v lese pre 59 zrážkových udalostí meraných v období 13. 5. -13. 10. 2009; vl'avo - zrážkové úhrny na vol'nej ploche v intervale $0-5 \mathrm{~mm}$; vpravo - zrážkový úhrn na vol’nej ploche prekročil $5 \mathrm{~mm}$; uhlopriečky predstavujú čiary $1: 1$; sivá čiara v pravej časti obrázka predstavuje regresnú čiaru $\left(\mathrm{R}^{2}=0.778\right)$.

Better relationships between the open area rainfall and throughfall appeared when total amounts of rainfall per individual events were aggregated and compared. We have analysed 59 events from period 13 May-13 October 2009. Fig. 2 shows the influence of rainfall amount on interception (percentage of rainfall which did not appear in throughfall). If the open area rainfall during an event was below 5 $\mathrm{mm}$, the correlation with throughfall was weak (Fig. 2 left). Nevertheless, except three outliers, throughfall in such instances never exceeded $2 \mathrm{~mm}$ and for most events it was below $1 \mathrm{~mm}$. It indicates that maximum canopy storage capacity was about 3-4 $\mathrm{mm}$. When the open area rainfall during a rainfall event exceeded the threshold of $5 \mathrm{~mm}$, throughfall became well correlated with the open area rainfall (Fig. 2 right). Linear regression explained 78\% of variability of the data. It indicates the canopy storage capacity of about 4 millimeters.

Fig. 3 shows the effect of rainfall duration in the open area rainfall-throughfall relationship. Rainfall durations for the 59 events varied between 30 and 1480 minutes. About one third of the rainfalls were shorter than 120 minutes and about one third of them were longer than 6 hours. Correlation of throughfall with open area rainfall was much better for the rainfall events longer than 120 minutes than for the shorter ones (Fig. 3). This "rain duration effect" is obviously partially connected also with the effect of total amount of the rainfall during an event described above. Canopy storage capacity indicated in the right panel of Fig. 3 is about 3 millimeters. Fig. 3 shows that summer storms bringing a lot of rain in a short period did not occur at the studied site in the studied period.

Statistics of the interception for individual events is given in Tab. 1. Individual rainfall events were divided according to rainfall depth and duration. Mean values indicate that studied forest had a significant influence on throughfall. However, very high variability of interception for individual rainfall events (Tab. 1, Fig. 4) should not be omitted.

Correlation between mean intensities of individual rainfall events in the open area and in the forests was not very strong (Fig. 5). As expected, the intensities in the open area were mostly higher than those in the forest.

\section{Discussion}

The existence of no correlation between the 10minutes open area rainfall and throughfall shown in Fig. 1 confirms findings of Vrugt et al. (2003) who demonstrated that measured throughfall dynamics contained limited information for calibration of an interception model and were particularly inadequate to identify the canopy storage capacity. Similar concerns were recently raised also by Zimmerman et al. (2010). 

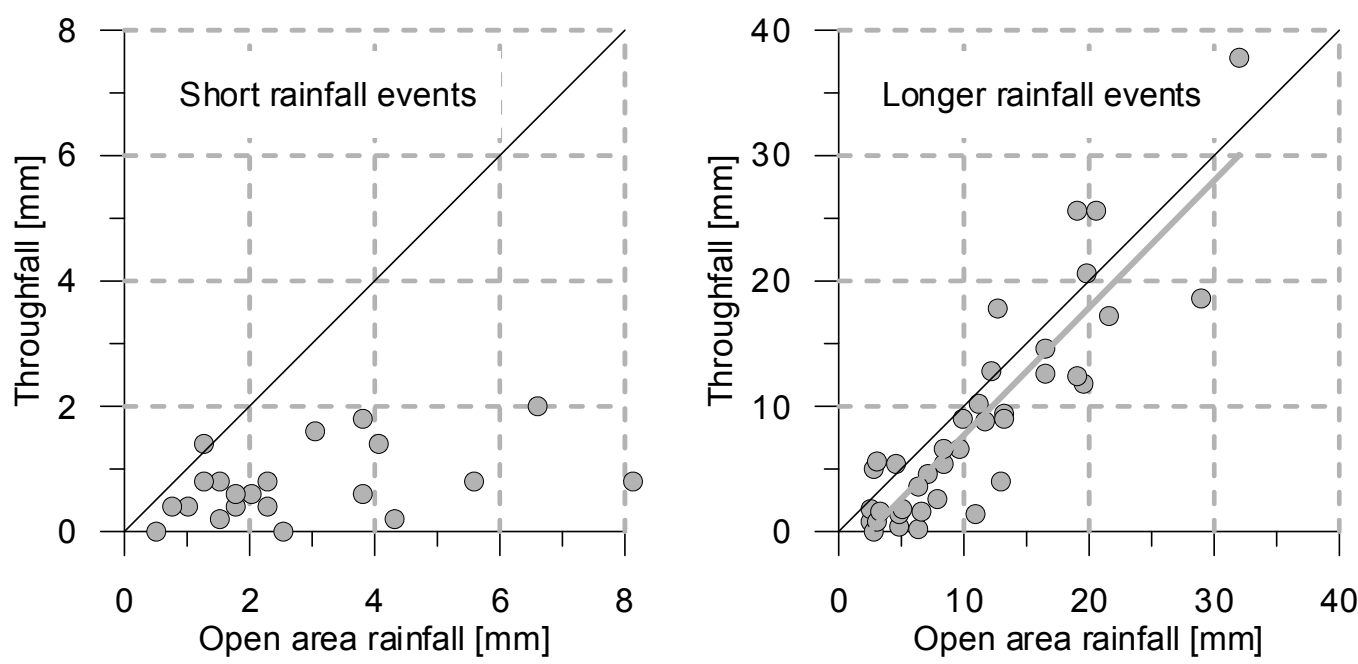

Fig. 3. Rainfall duration and interception; relationships between open area rainfall and throughfall for events with different duration; left - rainfalls shorter than 120 minutes; right - rainfalls longer than 120 minutes; the diagonals represent the 1:1 lines; the grey line in the right panel represents the regression line $\left(R^{2}=0.781\right)$.

Obr. 3. Dížka trvania dažd’a a intercepcia; vzt’ah medzi zrážkami na vol'nej ploche a podkorunovými zrážkami pre udalosti s rôznou dížkou trvania; vl’avo - zrážky kratšie ako 120 minút; vpravo - zrážky dlhšie ako 120 minút; uhlopriečky predstavujú čiary $1: 1$; sivá čiara v pravej časti obrázka predstavuje regresnú čiaru $\left(\mathrm{R}^{2}=0.781\right)$.

$\mathrm{T}$ a b 1 e 1. Interception of individual rainfall events; N1 - number of all rainfall events, N2 - number of rainfall events for which the interception was negative, i.e. throughfall exceeded the open area rainfall; other statistics (mean, minimum, maximum, standard deviation and $C v$ ) are given first for all events (i.e. N1), second only for events with positive interception (i.e. N1-N2).

$\mathrm{T}$ a b u l' k a 1. Intercepcia (percento zrážok zachytených lesom) jednotlivých zrážkových udalostí; N1 - počet všetkých zrážkových udalostí, N2 - počet zrážkových udalostí, pre ktoré bola negatívna intercepcia, t.j. podkorunové zrážky prevyšovali zrážky na vol'nej ploche; d’alšie štatistiky (priemer, minimum, maximum, smerodajná odchýlka, koeficient variácie) sú vypočítané najprv pre N1 a potom pre N1-N2.

\begin{tabular}{ccccc}
\hline & \multicolumn{2}{c}{ Rainfall amount } & \multicolumn{2}{c}{ Rainfall duration } \\
\cline { 2 - 5 } & Below 5 mm & Above 5 mm & Below 2 hours & Above 2 hours \\
\hline N1 & 28 & 31 & 21 & 38 \\
N2 & 4 & 6 & 1 & 9 \\
Mean [\%] & $53 / 70$ & $33 / 46$ & $68 / 72$ & $28 / 48$ \\
Minimum [\%] & $-84 / 29$ & $-40 / 9$ & $-10 / 37$ & $-84 / 9$ \\
Maximum [\%] & $100 / 100$ & $97 / 97$ & $100 / 100$ & $100 / 100$ \\
St. deviation [\%] & $48 / 20$ & $37 / 27$ & $26 / 19$ & $45 / 27$ \\
$C_{v}$ & $0.90 / 0.29$ & $1.12 / 0.60$ & $0.38 / 0.26$ & $1.58 / 0.57$ \\
\hline
\end{tabular}

Usefulness of the short time resolution data became more evident when the data for individual rainfall events were processed. The short-time resolution data allow detection of individual rainfall events which may not be recognized in data with longer time resolution, e.g. daily data. Correlations between the open area rainfall and throughfall in this study became detectable for the rainfall events exceeding certain rainfall depth (about $5 \mathrm{~mm}$ in the open area) or for rainfall events longer than 2 hours.

The canopy storage capacity for individual events varied. Its upper limit (about $4 \mathrm{~mm}$ ) is close to the value of $5 \mathrm{~mm}$ found in previous research in the region based on daily data (Majerčáková,
1983). Mind'áš et al., 2001 in their review paper on the water balance of the forest ecosystem in the Carpathians reported that the canopy stogare capacity of the forests reach approximately $10 \mathrm{~mm}$. We did not analyze influence of other factors such as wind speed on canopy storage capacity.

Mean values of interception given in Tab. 1 indicates high influence of the forest on throughfall. However, Fig. 4 and statistics in Tab. 1 show a very high variability and decreasing role of the forest for higher rainfall depths. Thus the mean values given in Tab. 1 should be taken with care. 

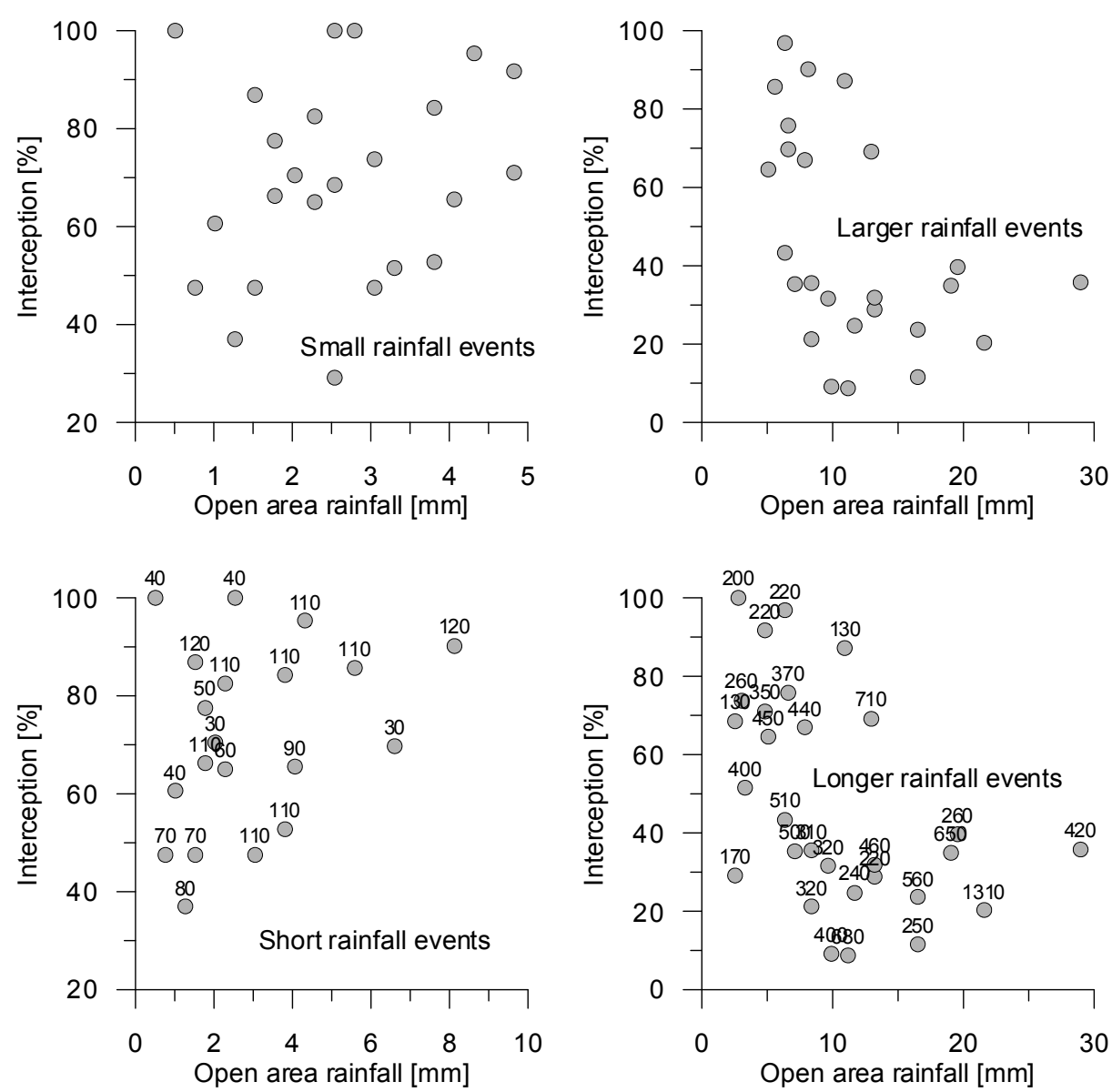

Fig. 4. Variability of interception for individual rainfall events against rainfall depth and duration; only the events with positive interception are shown, labels in the lower panel denote rainfall durations in minutes.

Obr. 4. Variabilita intercepcie pre jednotlivé zrážkové udalosti v závislosti od úhrnu a dĺžky trvania dažd’a; znázornená je len pozitívna intercepcia; čísla v spodnej časti obrázku ukazujú dížku trvania dažd’a v minútach.

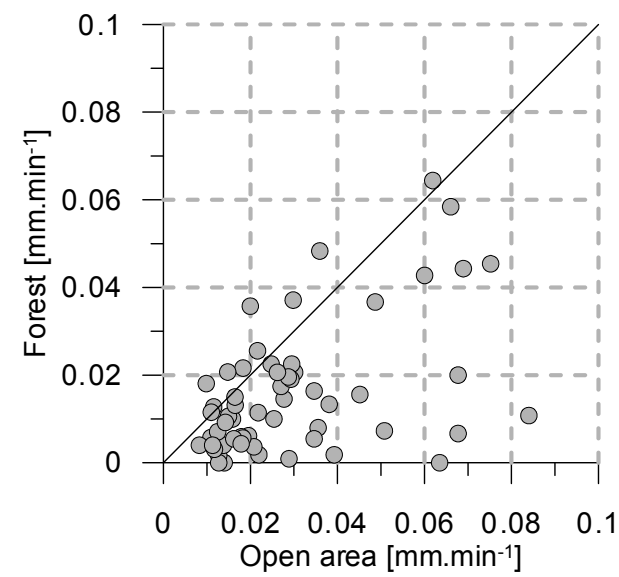

Fig. 5. Mean rainfall intensities of individual rainfall events in the open area and in the forest (59 events); the diagonal represents the $1: 1$ line.

Obr. 5. Priemerná intenzita jednotlivých zrážkových udalostí na otvorenej ploche a v lese (59 udalostí); uhlopriečka predstavuje čiaru $1: 1$.
Interception of individual rainfall events seems to be higher than the values calculated from biweekly data in our previous study (Holko et al., 2009). However, in this study we could use only one raingauge to measure throughfall. A much higher number of gauges at more locations would be necessary to generalize the results presented here. Although Keim et al (2005) showed that the spatial patterns of throughfall variability tend to persist, a large number of raingauges (either fixed or moving) is needed to describe it (e.g. Holwerda et al., 2006). Use of recording clusters of long troughs was proposed by Zimmermann et al. (2010) as a more promising sampling scheme. New measuring approaches represent other options. For example, Vrugt et al. (2003) reported that microwavemeasured canopy water storage dynamics provided sufficient information for identification of parameters of a physically based interception model. Friesen et al. (2008) recently presented the results 
of a new direct and nondestructive method to measure the whole-tree interception based on measurement of trunk compression by mechanical displacement sensors.

\section{Conclusions}

The short-time rainfall and throughfall data allow some analyses which can not be performed with data measured in the longer time resolution (e.g. delay of throughfall onset and termination, elimination of small rainfalls by the forest, comparison of rainfall intensities, analyses of interception during individual rainfall events). The 10-minutes data did not provide exact values which could be directly used as parameters of interception models, e.g. canopy storage capacity. However, unlike the longer-term measurements they allow discrimination of individual events which are more useful in the assessment of the thresholds. Information on varying canopy storage capacity during individual rainfall events could be used in validation and constraining of modeled interception giving the ranges in which the simulated results should vary. The study showed that interception of smaller rainfall events (under $5 \mathrm{~mm}$ ) was on average about doubled compared to interception of rainfall events with total depth exceeding $5 \mathrm{~mm}$. It can therefore be supposed that high interception values reported in many studies for annual or seasonal values indicate that most rainfalls in the studied areas were relatively small (below certain thresholds). Further studies at more locations and with better instrumentation would be useful to generalize the results presented in this study.

Acknowledgement. This work was supported by the grant VEGA -2/0079/08.

\section{REFERENCES}

BENETIN J., 1983: Analytical solution of relationship between transpiration and evaporation from interception. J. Hydrol. Hydromech., vol. 31, no. 3-4, 354-368.

BENETIN J., NOVÁK V., ŠOLTÉSZ A., ŠTEKAUEROVÁ V., 1986: Rain interception and its influence on water balance of the vegetation cover. (In Slovak.) J. Hydrol. Hydromech, vol. 43, no. 1, 3-24.

CALDER I., 1986: A stochastic model of rainfall interception. J. Hydrol., 89, 65-71.

FRIESEN J., VAN BEEK C., SELKER J., SAVENIJE H.H.G., and VAN DE GIESEN N., 2008: Tree rainfall interception measured by stem compression. Water Resour. Res., 44, W00D15, doi:10.1029/2008WR007074.

GASH J., 1979: An analytical model of rainfall interception by forest. Quarterly J. of the Royal Meteorolog. Soc., 105, $43-55$.
HALMOVÁ D., PEKÁROVÁ P., MIKLÁNEK P., 2006: Rainfall interception in hornbeam and spruce forest in Slovakia. Meteorol. J., vol. 9, no. 3-4, 123-130.

HELVEY J.D., PATRIC J.H., 1965: Canopy and Litter Interception of Rainfall by Hardwoods of Eastern United States. Wat. Resour. Res., 1, 2, 193-206.

HOLKO L., ŠKVARENINA J., KOSTKA Z., FRIČ M., STARON, J., 2009: Impact of spruce forest on rainfall interception and seasonal snow cover evolution in the Western Tatra Mountains, Slovakia. Biologia, 64/3, Section Botany, 594-599, DOI: 10.2478/s11756-009-0087-6.

HOLWERDA, F., SCATENA, F.N., BRUIJNZEEL, L.A., 2006: Throughfall in a Puerto Rican lower montane rain forest: A comparison of sampling strategies. J. Hydrol., 327, 592-602.

HORVÁT O., HLAVČOVÁ K., KOHNOVÁ S., DANKO M., 2009: Application of the FRIER distributed model for estimating the impact of and use changes on the water balance in selected basins in Slovakia. J. Hydrol. Hydromech., vol. 57, no. 4, 213-225.

KEIM R.F., SKRAUGSET A.E., WEILER M. 2005: Temporal persistence of spatial patterns in throughfall. J. Hydrol., 314, 263-274.

KREČMER V., 1952: Influence of forests on precipitation. (In Czech.) Meteorol. zprávy, vol. 5, no. 4, 106-116.

LANČARIČ P., MINĎÁŠ J., ŠKVARENINA J., 2001: Forest stand intercepion in mountain catchment in the Low Tatras. (In Slovak.) Bioklimatologické pracovné dni 2001: Extrémy prostredia (počasia) - limitujúce faktory bioklimatologických procesov, Račkova dolina, Slovakia.

LIU J., 1988: A theoretical model if the process of rainfall interception in forest canopy. Ecological Modelling, pp. 111-123.

MAJERČÁKOVÁ O., 1983: Interception as component influencing runoff generation from precipitation in forest biomes. (In Slovak.) [PhD Thesis.] Ústav hydrológie a hydrauliky SAV, Bratislava, $95 \mathrm{pp}$.

MASSMAN W., 1983: The derivation and validation of a new model for the interception of rainfall by forest. Agricultural Meteorology, 28, 261-286.

MIKLÁNEK P., PEKÁROVÁ P., 2006: Interception assessment in experimental microbasins of IH SAS with spruce and hornbeam vegetation. (In Slovak with an English abstract.) J. Hydrol. Hydromech., vol. 54, no. 2, 123-136.

MINĎÁŚ J., 2001: Influence of rainfall intensity on interception process in midmountain forests of Pol'ana. In Slovak. Bioklimatologické pracovné dni 2001: Extrémy prostredia (počasia) - limitujúce faktory bioklimatologických procesov, Račkova dolina, Slovakia.

MINĎÁŠ J., ŠKVARENINA J., STŘELCOVÁ K., 2001: Importance of forests in the landscape hydrological regime. (In Slovak.) Životné prostredie, vol. 35, no. 3.

MULDER J. 1985: Simulating interception loss using standard meteorological data. In: Hutchison B., Hicks B. (Eds.), The Forest-Atmosphere Interaction. Reidel Publishing Company, Dordrecht, 77-196.

MURAKAMI S., 2007: Application of three canopy interception models to a young stand of Japanese cypress and interpretation in terms of interception mechanism. J. Hydrol., 342, 305-319.

MUZYLO A., LLORENS P., VALENTE F., KEIZER J.J., DOMINGO F., GASH J.H.C., 2009. A review of rainfall interception modeling. J. Hydrol., 370, 191-206. 
PEKÁROVÁ P., KONÍČEK A., MIKLÁNEK P., 2005: Impact of land use on runoff regime in experimental microbasins of IH SAS. (In Slovak.) Bratislava, Veda, 216 pp.

RUTTER A., KERSHAW K., ROBINS P., MORTON A., 1971: A predictive model of rainfall interception in forest. 1. Derivation of the model from observation in a plantation of Corsican pine. Agricultural Meteorology, 9, 367-384.

SAVENIJE H.H.G., 2004: The importance of interception and why we should delete the term evapotranspiration from our vocabulary. Invited Commentary. Hydrol. Process., 18, $1507-1511$.

TUŽINSKÝ L., 1995: The effect of felling intensity on the components of water balance in spruce ecosystem. Lesníc. Čas., 41, no. 4, 231-241.

VALTÝNI J., 1986: Water management and flood protection role of the forest. (In Slovak.) Lesnícke štúdie VÚLH vo Zvolene, 38, $68 \mathrm{pp}$.

VRUGT J.A., DEKKER S.C., BOUTEN W., 2003: Identification of rainfall interception model parameters from measurements of throughfall and forest canopy storage. Water Resour. Res., 39, no. 9, 1251, doi:10.1029/2003WR002013.

XIAO Q., MCPHERSON E.G., USTIN S.L., GRISMER M.E., 2000: A new approach to modeling tree rainfall interception. Water Resour. Res., 105, no. D23, 29173-29188.

ZELENÝ V., TICHÝ J., 1968: Snow conditions in a spruce stand and on a cut area in the Moravian-Silesian Beskydes. (In Czech.) Lesnic. Čas., 14, (XLI), 803-816.

ZENG N., SHUTTLEWORTH J., GASH J., 2000: Influence of temporal variability of rainfallon interception loss. Part 1 . Point analysis. J. Hydrol., 228, 228-241.

ZIMMERMANN B., ZIMMERMANN A., LARK R.M., ELSENBEER H., 2010: Sampling procedures for throughfall monitoring: A simulation study, Wat. Resour. Res., 46, W01503, doi:10.1029/2009WR007776.

Received July 13, 2010

Accepted October 26, 2010

\section{MERANIE INTERCEPCIE V HORSKOM SMREKOVOM LESE V KRÁTKOM ČASOVOM KROKU}

\section{Ladislav Holko}

Intercepcia je jedným z procesov, ktorým vplýva vegetácia na hydrologický cyklus. Výskumom intercepcie sa zaoberali a zaoberajú stovky štúdií na celom svete. V Európe sa porovnávacie merania zrážok na otvorenej ploche a v lese vykonávali už v 19. storočí (Krečmer, 1952), v USA od prvej tretiny 20. storočia (Helvey, Patrick, 1965). Výsledky takýchto štúdií často charakterizujú priemernú intercepciu za dlhšie časové odobie, napr. rok alebo sezónu. Takéto údaje sú užitočné napríklad pri analýze hydrologickej bilancie, ale v iných prípadoch, napr. pri hydrologickom modelovaní, výskume tvorby odtoku v povodí, rozdelenia vlhkosti pôdy alebo erózie sú užitočnejšie poznatky o intercepcii v kratšom časovom intervale (napr. intercepcia jednotlivých dažd'ov).
V takýchto prípadoch býva obyčajne potrebné využitie matematického modelovania. Modelovanie intercepcie sa postupne vyvíjalo od empirických a štatistických modelov $\mathrm{k}$ fyzikálne založeným modelom, ktoré sa môžu rozdelit' zhruba do troch skupín (Xiao et al., 2000; Muzylo, 2009):

- modely typu Ruttera (1971),

- modely typu Gasha (1979),

- modely Caldera (1986).

Základné vzt'ahy pri modeloch prvých dvoch typov sú opísané rovnicami (1)-(4). Ako vidiet', tieto rovnice obsahujú vel'a parametrov, ktoré sú často len kalibrované, lebo sa t’ažko overujú meraniami (Vrugh et al., 2003). Ciel'om tohto príspevku bolo porovnanie meraní zrážok na vol'nej ploche a v smrekovom lese, vykonávaných v krátkom časovom kroku, vyhodnotenie intercepcie jednotlivých zrážkových udalostí a užitočnosti takýchto meraní pri určovaní parametrov fyzikálne založených modelov interecpcie spojených napr. s množstvom vody zachyteným vegetáciou.

Merania boli vykonávané v povodí Jaloveckého potoka v Západných Tatrách v nadmorskej výške $1500 \mathrm{~m}$ n.m. a v blízkom smrekovom lese (priemerný vek 110 rokov) v teplej časti roka 2009 pomocou preklápacích zrážkomerov. Podl'a predchádzajúcich meraní (Holko et al., 2009) bola variabilita intercepcie v porastových oknách na danej lokalite menšia ako v iných typických lokalitách (zóna odkvapu, zrážky pri kmeni). Preto bol preklápací zrážkomer v lese umiestnený v porastovom okne. Porovnanie 10-minútových dažd’ov neukázalo dobrý vzt'ah medzi zrážkami na vol'nej ploche a v lese (obr. 1). Lepšie výsledky boli získané pri porovnávaní sumárnych úhrnov za jednotlivé zrážkové udalosti (obr. 2 a 3). Pri prekročení určitého úhrnu (cca $5 \mathrm{~mm}$ ) alebo dížky trvania dažd'a (cca 120 minút) sa vzt'ah medzi zrážkami na vol'nej ploche a v lese výrazne zlepšil. Výsledky práce ukázali, že okamžité, resp. 10-minútové údaje nepriniesli informácie, ktoré by pomohli pri priamom určení parametrov fyzikálne založených modelov intercepcie. Spracovanie krátkodobých údajov pre jednotlivé dažde síce tiež neurčilo jednoznačne hodnotu retenčnej kapacity vegetácie, ale ukázalo približne jej rozsah, resp. maximum na skúmanej lokalite (cca $5 \mathrm{~mm}$ ). Priemerná intercepcia dažd'ov, pri ktorých celkový úhrn na vol'nej ploche prekročil hodnotu $5 \mathrm{~mm}$, bola približne polovičná v porovnaní s dažd'ami, ktoré mali úhrn menší ako $5 \mathrm{~mm}$ (tab. 1, obr. 4). Preto sa dá predpokladat', že výsledky štúdií, pri ktorých boli zistené vel'ké hodnoty ročnej alebo sezónnej intercepcie, poukazujú na to, že väčšina dažd'ov v skúmaných lokalitách bola pomerne malých (pod určitou „kritickou“ hodnotou). Priemerná intercepcia jednotlivých zrážkových udalostí bola vel'ká, ale tab. 1 a obr. 4 ukazujú aj jej vel'kú variabilitu. 